\title{
Studies on Shelf Life Extension of Paneer with the Addition of Plant Essential Oil and Different Packaging Materials
}

\author{
Anju Boora Khatkar ${ }^{1 *}$, Aradhita $\operatorname{Ray}^{1}$ and Amarjeet Kaur ${ }^{2}$ \\ ${ }^{1}$ Department of Food Technology, Guru Jambheshwar University of Science and Technology, \\ Hisar- 125001, Haryana, India \\ ${ }^{2}$ Department of Food Science and Technology, Punjab Agricultural University, \\ Ludhiana - 141004, Punjab, India \\ *Corresponding author
}

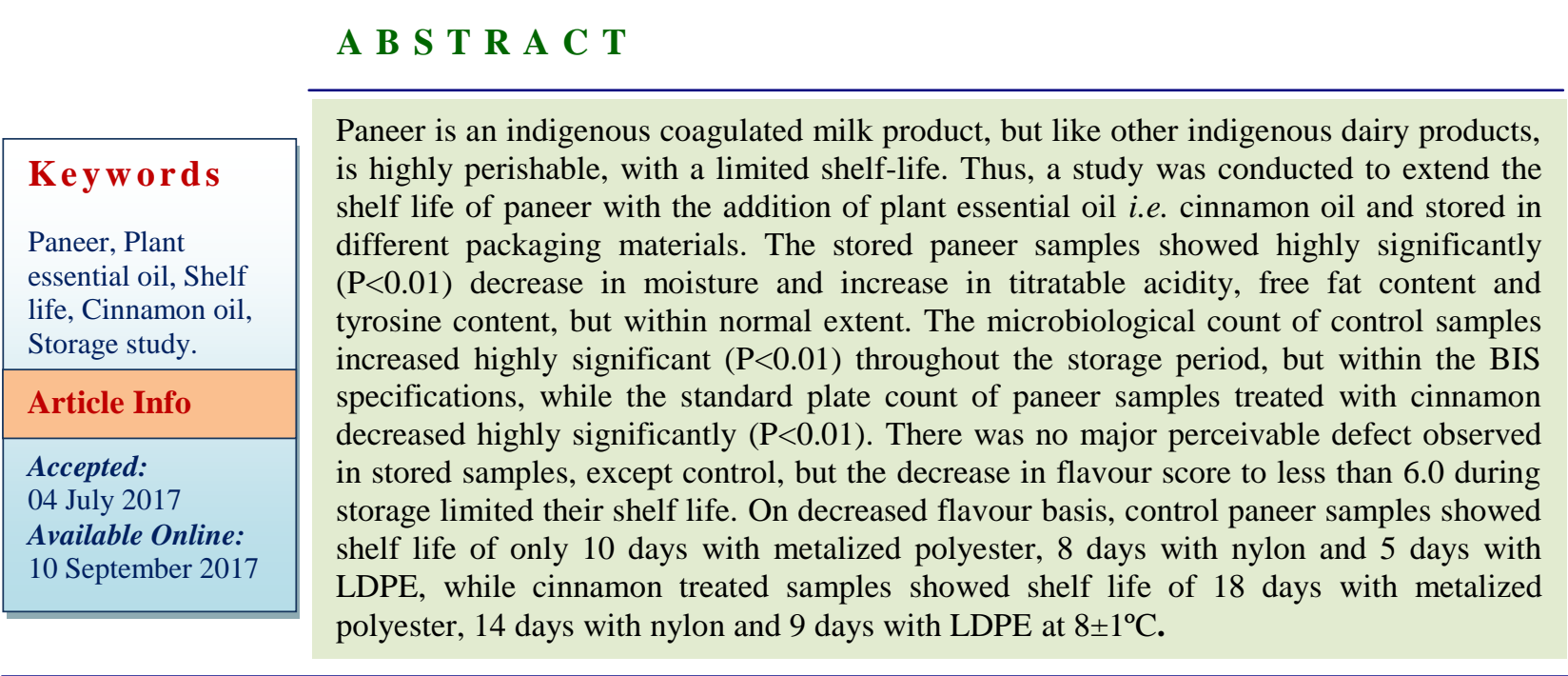

\section{Introduction}

In current scenario, India is 'The Oyster' in the market of international dairy industry and total milk production is estimated to be about 155.5 MT in 2015-16 (Anonymous, 2017). Further, India contributes about $17-18 \%$ of world's total milk production. Out of which, buffalo milk contributes $55 \%$ and cow milk $40.5 \%$ of total milk production. Hence, there is a good potential and availability of milk for the preparation of milk products in India. Paneer is an indigenous coagulated milk product prepared by the addition of permitted organic acids to hot milk and subsequent drainage of whey. Paneer consists of entire milk casein, part of denatured whey proteins, almost all fat, colloidal salts and soluble milk solids in proportion to the moisture content retained. The characteristics features of paneer is a typical mild acidic flavour with slightly sweet taste and has a firm, cohesive and spongy body and a close knit smooth texture. Paneer, like other indigenous dairy products, is a highly perishable product and suffers from limited shelf-life, largely because 
of its high moisture content (approx. 55\%). When fresh paneer is stored at higher temperatures, particularly prevailing during summer months, its shelf-life gets reduced to less than one day. Its shelf-life is reported to be only 6 days under refrigeration $\left(10^{\circ} \mathrm{C}\right)$, though its freshness is lost within three days (Bhattacharya et al., 1971). The heat treatment given to milk is sufficient to destroy all the pathogenic and most of the other microorganisms. The technology of paneer manufacturing allows considerable exposure of paneer with large volumes of water and air during manufacture and packaging. During this period, the microorganisms enter and establish themselves in the product. It is this contamination which is responsible for the spoilage of paneer. It has been observed that the spoilage in paneer occurs due to the growth of microorganisms which bring about various physico-chemical changes leading to the development of various off-flavours in the product. Thus, paneer must be consumed fresh. This is the major handicap in the industrial adoption of paneer production. It is, therefore, very much essential to find out suitable means of extending the shelf-life of paneer.

Various processing procedures like thermal processing, freezing, drying, concentration and irradiation are the main tools for controlling the microbial, chemical and physical deteriorations in the foods. However, other processing procedures also need to be employed because of a variety of constraints associated with certain types of foods and because of the lack of effectiveness of certain physical methods. One such procedure is the use of food additives which are natural or artificial chemical agents mainly employed to retard microbial growth with their antimicrobial activity and are commonly called food preservatives. Antimicrobial compounds present in foods can also extend shelf-life of unprocessed or processed foods by reducing microbial growth rate or viability (Beuchat and Golden, 1989). Originally added to change or improve taste, spices and herbs can also enhance shelf-life because of their antimicrobial nature. Some of these same substances are also known to contribute to the self-defense of plants against infectious organisms (Deans and Ritchie, 1987; Kim et al., 2001). Essential (volatile) plant oils occur in edible, medicinal and herbal plants, which minimize questions regarding their safe use in food products. Essential oils along with their constituents have been extensively explored as flavouring agents in foods since the initial ages and it is well established that many have wide spectra of antimicrobial action (Kim et al., 1995a; Packiyasothy and Kyle, 2002; Alzoreky and Nakahara, 2002). The antimicrobial property of essential oil depends upon their composition, structure as well as functional groups (Deans et al., 1995; Dorman and Deans, 2000) and usually they are having several active compounds like eugenol (allspice, clove bud and leaf, bay, and cinnamon leaf), cinnamamic aldehyde (cinnamon bark, cassia oil) and citral which are having strong antimicrobials activity (LisBalchin et al., 1998b; Davidson and Naidu 2000). Thus, plant essential oils could also be good alternatives to heat and chemical preservatives in the field of food and dairy science, which is still unexplored for practical application. Further, to the best of authour' knowledge, there is zilch regarding such type of studies in the literature concerning the use of essential oil along with variable packaging materials for direct application in milk and milk products. Hence, keeping all these points in mind present study was planned to enhance the shelf life of paneer employing natural antimicrobial system.

\section{Materials and Methods}

Pasteurized full fat buffalo milk (6\% fat and 9\% SNF) was procured from Milk Parlour of 
the Vita Milk Plant, Jind and other chemicals and reagents of analytical grade were procured from S. D. Fine Chem. Ltd., Mumbai. Food grade cinnamon plant essential oils were procured from SABRI ITTAR 1/6, Jamal Mainsion Nowroji Hill Road No 1, Dongri. Mumbai-400009 (INDIA) and packaging materials were procured from Hitkari packaging Company, Parmanoo, Himachal Pradesh, India.

\section{Preparation of paneer}

In present study, paneer samples were prepared by following the standard method (Bhattacharya et al., 1971). The vat and wooden stirrer were thoroughly cleaned and sterilized. Then filtered/ clarified and standardized (6\% fat and 9\% SNF) milk was taken in the vat. Occasional stirring was done during heating of milk, in order to prevent skin formation. The temperature of milk was raised to $80^{\circ} \mathrm{C}$ and maintained for $30 \mathrm{~min}$ followed by cooling to $70^{\circ} \mathrm{C}$, and then coagulant ( $1 \%$ citric acid solution heated up to $70^{\circ} \mathrm{C}$ ) @ $0.25 \%$ of milk was added in a thin continuous stream till complete coagulation was achieved as evidenced from the clarity of whey (greenish white tinge). The speed of stirring of milk during addition of the coagulant solution was maintained at 30-40 motions of the stirrer per min.

The time taken for addition of the coagulant was approximately $60-80 \mathrm{sec}$. The $\mathrm{pH}$ of whey ranged from 5.6 to 5.5. Before draining the whey, the contents of the vat were left undisturbed for $15 \mathrm{~min}$. The coagulated mass was then collected in muslin cloth. Pressure was applied on the top of the coagulant mass by placing weight of app. $2 \mathrm{~kg}$ for about 15 min. The pressed paneer was removed from the muslin cloth, and cut into 2-3" size pieces, which were then immersed in chilled water $\left(4^{\circ} \mathrm{C}\right)$ for $2-3 \mathrm{~h}$. The pieces of chilled paneer were then removed from water and placed on wooden planks for about 10-15 min to allow loose water to drain.

Packaging and storage of paneer in different packaging materials

Packaging materials, namely LLD/ BA*/Nylon-6/BA*/LDPE (110 micron) (*poly binding agent), Unprinted metalized polyester-LDPE laminates and LDPE pouch were used for packaging and storage of paneer samples. Immediately before packaging of paneer samples, the empty packages were sterilized under UV-light for $30 \mathrm{~min}$ and after that paneer samples were packed in these packaging materials under hygienic atmospheres (air) by using vertical heat-stealing machine. The paneer blocks of $50 \mathrm{gm}$ each were packed in different packaging material and stored at $8 \pm 1{ }^{\circ} \mathrm{C}$ and evaluated for storage studies.

\section{Sampling}

The fresh and stored $\left(8 \pm 1{ }^{\circ} \mathrm{C}\right)$ paneer samples were tempered at $15.5^{\circ} \mathrm{C}$ for $1 \mathrm{~h}$ before analysis. The sampling of paneer was done as per the procedure detailed in ICAR Bulletin No. 70 (1951) for chhana. About 20 gm Paneer from different portions of the entire mass was taken with a trier and pooled together. It was then passed through grater and transferred to screw cap sample bottles for analysis.

\section{Physico-chemical analysis}

The moisture content of the paneer samples was determined by the method as outlined in IS: 10484-1983. For estimating the fat content of paneer samples by using cheese butyrometer, the method prescribed in IS: 1977: 1224 (Part II) was adopted. The protein content of paneer was determined by semimicro Kjeldahl method described by Manefee and Overman (1940) using Kjeltec digestion 
and distillation equipment (2300, Kjeltec Analyzer, FOSS) followed by manual distillation and titration method. Lactose content of samples was determined as per method described by Lawrence (1968). The ash content of paneer sample was determined gravimetrically as per the method of BIS (2001a). Titratable acidity of paneer samples was determined by following the method prescribed for cheese by the AOAC (1975).

The fat breakdown in paneer samples was determined by estimating free fatty acid (FFA) as \% oleic acid adopting the procedure of Thomas et al., (1954). Proteolytic changes in terms of tyrosine content in stored paneer samples were estimated by the procedure suggested by Hull (1947). The microbiological quality of freshly prepared and stored paneer samples were analysed according to the standard methods i.e. total plate count (Rai, 2004), yeast and mould counts and coliform counts (APHA, 1978).

\section{Sensory evaluation of paneer}

The fresh/stored samples of paneer packaged in the high barrier bags and stored under refrigeration condition, were evaluated organoleptically by a panel of six trained judges for appearance, flavour, body \& texture and overall acceptability. The test samples of paneer stored at $8 \pm 1^{\circ} \mathrm{C}$ were tempered at $15.5^{\circ} \mathrm{C}$ for $1 \mathrm{~h}$ before presenting to the judges under code numbers. The samples were evaluated by judges using a 9point Hedonic Scale. The judges were also asked to note their observations on nine point hedonic scale score cards.

\section{Statistical analysis}

The data obtained were subjected to analysis of variance (i.e. one way anova and two way anova without interaction) and employing appropriate computer packages under the guidance of a statistician. Wherever required, the overall mean and standard deviation of the compositional data was also calculated.

\section{Results and Discussion}

\section{Chemical composition}

The gross chemical composition of paneer is given in table 1 . The composition of paneer in our study was similar to what has been reported earlier by Bhattacharya et al., 1971, Pal and Garg, 1989, Sweta, 2004 and Srivastava, 2004.

\section{Effect of storage on physic-chemical properties}

\section{Changes in moisture content}

\section{Control samples}

There was highly significantly $(\mathrm{P}<0.01)$ decrease in moisture content of control sample with the increase in storage period from an initial 52.221 to 51.621 in 10 days, to 51.723 in 8 days and to 51.612 in 5 days when packed with MP, NP and LDPE, respectively, but with slight extent i.e. within $1 \%$ throughout the storage periods (Table 1 and Figure 1).

\section{Cinnamon treated samples}

Further, during the storage of cinnamon treated paneer samples, there was highly significantly $(\mathrm{P}<0.01)$ decrease in moisture content when packed in different packaging material with the increase in storage period, but with slower extent as compared to control paneer samples. It was observed that the moisture content of paneer samples treated with cinnamon decreases from an initial 52.221 to 51.772 in 18 days with MP, to 51.611 in 14 days with NP and to 51.011 in 9 days with LDPE (Table 1 and Figure 1). 
Similar trend of decrease in moisture content of paneer during storage were also observed earlier by Rao et al., 1984, Mistry et al., 1990, Pal et al., 1993 and Pal, 1998. The gradual decrease in moisture content of paneer during storage was mostly due to expulsion of moisture from the product to surrounding, but with slower rate that might be mostly due to oily layer formed on the surface of paneer samples which act as a barrier for moisture expulsion. There was less decrease in moisture content of cinnamon treated paneer sample during storage when packed in metalized polyester then in nylon based laminates as compared to LDPE pouches mostly due to high moisture barrier properties of metalized polyester laminates and nylon based laminates compared to LDPE.

\section{Changes in titratable acidity (\% LA)}

There was highly significantly $(\mathrm{P}<0.01)$ increase in titratable acidity of all the samples with the increase in storage period.

\section{Control samples}

Individually, the titratable acidity of control sample increased highly significantly $(\mathrm{P}<0.01)$ from an initial 0.16 to 0.38 in 10 days, to 0.32 in 8 days and to 0.43 in 5 days when packed with MP, NP and LDPE, respectively, (Table 1 and Figure 1). The increase in titratable acidity of control paneer sample is a natural process and with higher extent. The increase in titratable acidity of paneer during storage was also reported earlier by various research workers (Bhattacharya et al., 1971, Shukla et al., 1984, Pal and Garg, 1989 and Mistry et al., 1990).

There was less increase in titratable acidity of control paneer samples during storage when packed in metalized polyester then in nylon based laminates as compared to LDPE pouches usually due to high moisture and oxygen barrier properties of metalized polyester laminates and nylon based laminates compared to LDPE.

\section{Cinnamon treated samples}

The titratable acidity of paneer samples treated with cinnamon increased highly significantly $(\mathrm{P}<0.01)$ from an initial 0.16 to 0.32 in 18 days with MP, to 0.36 in 14 days with NP and to 0.35 in 9 days with LDPE (Table 1 and Figure 1). The increase in titratable acidity of cinnamon treated sample was slower than the control sample due to antimicrobial action of cinnamon plant essential oil. Similar results were obtained by Pal et al., (1993) during storage of wax coated fresh paneer.

There was less increase in titratable acidity of cinnamon treated paneer samples during storage when packed in metalized polyester then in nylon based laminates as compared to LDPE pouches mostly due to high barrier properties of metalized polyester laminates and nylon based laminates compared to LDPE.

\section{Changes in free fatty acid (\%)}

There was highly significantly $(\mathrm{P}<0.01)$ increase in free fatty acid of all the samples with the increase in storage period.

\section{Control samples}

The free fatty acid of control sample increased highly significantly $(\mathrm{P}<0.01)$ from an initial 0.175 to 0.517 in 10 days, to 0.491 in 8 days and to 0.541 in 5 days when packed with MP, NP and LDPE, respectively, (Table 1 and Figure 1), was mostly due to lipolysis action. The increase in free fatty acid of control paneer sample was similar to earlier reported value of Sindhu et al., (2000), Kumar (1989) and Rai et al., (2008), but it was within desirable range. 


\section{Cinnamon treated samples}

It was observed that the free fatty acid of cinnamon treated paneer samples increased highly significantly $(\mathrm{P}<0.01)$ from an initial 0.175 to 0.419 in 18 days with MP, to 0.448 in 14 days with NP and to 0.425 in 9 days with LDPE (Table 1 and Figure 1). The free fatty acid of cinnamon treated paneer samples increased with slower extent as compare to control samples and earlier reported values by Sindhu et al., (2000), Kumar (1989) and Rai (2008), that should be mostly due to antimicrobial action of cinnamon.

\section{Changes in tyrosine content}

There was highly significantly $(\mathrm{P}<0.01)$ increase in tyrosine content of all the samples with the increase in storage period.

\section{Control sample}

Individually, the tyrosine content of control sample increased highly significantly $(\mathrm{P}<0.01)$ from an initial 12.192 to 28.642 in 10 days, to 32.531 in 8 days and to 39.336 in 5 days when packed with MP, NP and LDPE, respectively, (Table 1 and Figure 1).
The increase in tyrosine content of control sample was increased steeply with the increase in storage period mostly due to more proteolysis action in stored product. Pal et al., (1993) and Pal (1998) also observed similar trends of increase in tyrosine content of fresh paneer sample when stored at $8 \pm 1^{\circ} \mathrm{C}$. There was less proteolysis of control sample when packed in metalized polyester then in nylon based laminates as compared to LDPE pouches mostly due to high moisture and oxygen barrier properties of metalized polyester laminates and nylon based laminates.

\section{Cinnamon treated sample}

The tyrosine content of paneer samples treated with cinnamon increased highly significantly $(\mathrm{P}<0.01)$ from an initial 12.192 to 29.914 in 18 days with MP, to 32.553 in 14 days with NP and to 31.585 in 9 days with LDPE, respectively, (Table 1 and Figure 1), but with slight extent. The increase in tyrosine content of cinnamon treated sample with the increase in storage period was lesser as compared to control sample and earlier reported values by Pal et al., (1993) and Pal (1998), mostly due to antimicrobial action of cinnamon plant essential oils.

Table.1 Gross Chemical Composition of Paneer

\begin{tabular}{|c|c|}
\hline Components & Mean \pm S.D.* \\
\hline Moisture (\%) & $\mathbf{5 2 . 1 9 \pm 0 . 2 9}$ \\
\hline Fat (\%) & $\mathbf{2 6 . 2 2 \pm 0 . 1 7}$ \\
\hline Protein (\%) & $\mathbf{1 7 . 0 9} \pm \mathbf{0 . 1 1}$ \\
\hline Lactose (\%) & $\mathbf{2 . 7 2 \pm 0 . 3 9}$ \\
\hline Ash (\%) & $\mathbf{1 . 7 8 \pm 0 . 0 5}$ \\
$*$ mean \pm S.D of 5 trials &
\end{tabular}


Table.2 Effect of storage (at $8 \pm 1^{\circ} \mathrm{C}$ ) on physic-chemical and microbiological attributes of control and cinnamon treated sample Packed under different packaging materials

\begin{tabular}{|c|c|c|c|c|c|c|c|c|c|c|c|c|c|}
\hline \multirow{2}{*}{ Characteristics } & \multirow{2}{*}{ Treatment } & \multirow{2}{*}{ Packaging Materials } & \multicolumn{10}{|c|}{ Storage Periods (Days) } & \multirow{2}{*}{ P-value } \\
\hline & & & $\mathbf{0}$ & 4 & 5 & 8 & 9 & 10 & 12 & 14 & 16 & 18 & \\
\hline \multirow{6}{*}{ Moisture (\%) } & \multirow{3}{*}{ Control } & LDPE & $52.221 \pm 0.002$ & $51.708 \pm 0.001$ & $51.613 \pm 0.001$ & - & - & - & - & - & - & - & $4.67 \mathrm{E}-15 * *$ \\
\hline & & \begin{tabular}{|l|} 
Nylon \\
\end{tabular} & $52.221 \pm 0.002$ & $52.084 \pm 0.001$ & - & $51.723 \pm 0.002$ & - & - & - & - & - & - & $2.35 \mathrm{E}-14 * *$ \\
\hline & & \begin{tabular}{|l|} 
Metalized Polyester \\
\end{tabular} & $52.221 \pm 0.002$ & $52.163 \pm 0.001$ & - & $51.871 \pm 0.002$ & - & $51.621 \pm 0.001$ & - & - & - & - & $4.14 \mathrm{E}-19 * *$ \\
\hline & \multirow{3}{*}{$\begin{array}{l}\text { Cinnamon } \\
\text { Treated }\end{array}$} & \begin{tabular}{|l|l} 
LDPE \\
\end{tabular} & $52.221 \pm 0.002$ & $51.785 \pm 0.001$ & - & $51.146 \pm 0.001$ & $51.011 \pm 0.001$ & - & - & - & - & - & $6.07 \mathrm{E}-22 * *$ \\
\hline & & Nylon & $52.221 \pm 0.002$ & $52.183 \pm 0.001$ & - & $51.899 \pm 0.001$ & - & - & $51.762 \pm 0.001$ & $51.611 \pm 0.001$ & - & - & $3.69 \mathrm{E}-24 * *$ \\
\hline & & Metalized Polyester & $52.221 \pm 0.002$ & $52.203 \pm 0.001$ & - & $52.031 \pm 0.001$ & - & - & $51.971 \pm 0.001$ & - & $51.873 \pm 0.001$ & $51.772 \pm 0.002$ & $5.34 \mathrm{e}-26^{* *}$ \\
\hline \multirow{6}{*}{$\begin{array}{l}\text { Titratable } \\
\text { acidity (\%LA) }\end{array}$} & \multirow{3}{*}{ Control } & LDPE & $0.16 \pm 0.01$ & $0.25 \pm 0.01$ & $0.43 \pm 0.01$ & - & - & - & - & - & - & - & $5.46 \mathrm{E}-09 * *$ \\
\hline & & Nylon & $0.16 \pm 0.01$ & $0.22 \pm 0.01$ & - & $0.32 \pm 0.01$ & - & - & - & - & - & - & $4.25 \mathrm{E}-08^{* * *}$ \\
\hline & & \begin{tabular}{|l|} 
Metalized Polyester \\
\end{tabular} & $0.16 \pm 0.01$ & $0.179 \pm 0.01$ & - & $0.24 \pm 0.01$ & - & $0.38 \pm 0.01$ & - & - & - & - & $2.18 \mathrm{E}-10 * *$ \\
\hline & \multirow{3}{*}{$\begin{array}{l}\text { Cinnamon } \\
\text { Treated }\end{array}$} & LDPE & $0.16 \pm 0.01$ & $0.19 \pm 0.01$ & - & $0.27 \pm 0.01$ & $0.35 \pm 0.01$ & - & - & - & - & - & $3.69 \mathrm{E}-10 * *$ \\
\hline & & \begin{tabular}{|l|} 
Nylon \\
\end{tabular} & $0.16 \pm 0.01$ & $0.18 \pm 0.01$ & - & $0.24 \pm 0.01$ & - & - & $0.33 \pm 0.01$ & $0.36 \pm 0.01$ & - & - & $1.18 \mathrm{E}-12 * *$ \\
\hline & & \begin{tabular}{|l|} 
Metalized Polyester \\
\end{tabular} & $0.16 \pm 0.01$ & $0.16 \pm 0.01$ & - & $0.22 \pm 0.01$ & - & - & $0.25 \pm 0.01$ & & $0.29 \pm 0.01$ & $0.32 \pm 0.01$ & $2.5 \mathrm{E}-13 * *$ \\
\hline \multirow{6}{*}{$\begin{array}{l}\text { Free fatty acid } \\
(\%)\end{array}$} & \multirow{3}{*}{ Control } & LDPE & $0.175 \pm 0.003$ & $0.417 \pm 0.003$ & $0.542 \pm 0.005$ & - & - & - & - & - & - & - & $8.86 \mathrm{E}-16 * *$ \\
\hline & & Nylon & $0.176 \pm 0.002$ & $0.384 \pm 0.001$ & - & $0.491 \pm 0.002$ & - & - & - & - & - & - & $2.17 \mathrm{E}-15^{* *}$ \\
\hline & & \begin{tabular}{|l|} 
Metalized Polyester \\
\end{tabular} & $0.175 \pm 0.001$ & $0.227 \pm 0.002$ & - & $0.388 \pm 0.001$ & - & $0.518 \pm 0.001$ & - & - & - & - & $3.08 \mathrm{e} .18^{* *}$ \\
\hline & \multirow{3}{*}{$\begin{array}{l}\text { Cinnamon } \\
\text { Treated }\end{array}$} & LDPE & $0.176 \pm 0.005$ & $0.285 \pm 0.002$ & - & $0.315 \pm 0.009$ & $0.426 \pm 0.008$ & - & - & - & - & - & $5.82 \mathrm{E}-17 * *$ \\
\hline & & Nylon & $0.175 \pm 0.001$ & $0.289 \pm 0.057$ & - & $0.292 \pm 0.004$ & - & - & $0.382 \pm 0.007$ & $0.449 \pm 0.005$ & - & - & $1.61 \mathrm{E}-06 * *$ \\
\hline & & \begin{tabular}{|l|} 
Metalized Polyester \\
\end{tabular} & $0.176 \pm 0.002$ & $0.217 \pm 0.008$ & - & $0.248 \pm 0.007$ & - & - & $0.306 \pm 0.006$ & & $0.371 \pm 0.001$ & $0.419 \pm 0.004$ & $1.35 \mathrm{E}-25 * *$ \\
\hline \multirow{6}{*}{$\begin{array}{l}\text { Tyrosine } \\
\text { content } \\
\text { (mg/100g) }\end{array}$} & \multirow{3}{*}{ Control } & LDPE & $12.194 \pm 0.01$ & $29.856 \pm 0.01$ & $39.337 \pm 0.02$ & - & - & - & - & - & - & - & $2.77 \mathrm{E}-24 * *$ \\
\hline & & \begin{tabular}{|l|} 
Nylon \\
\end{tabular} & $12.195 \pm 0.01$ & $24.54 \pm 0.230$ & - & $32.533 \pm 0.02$ & - & - & - & - & - & - & $4.7 \mathrm{E}-12 * *$ \\
\hline & & Metalized Polyester & $12.195 \pm 0.01$ & $21.189 \pm 0.01$ & - & $24.697 \pm 0.01$ & & $28.646 \pm 0.01$ & - & - & - & - & $7.19 \mathrm{E}-26 * *$ \\
\hline & \multirow{3}{*}{$\begin{array}{l}\text { Cinnamon } \\
\text { Treated }\end{array}$} & LDPE & $12.442 \pm 0.43$ & $19.785 \pm 0.02$ & - & $24.655 \pm 0.04$ & $31.585 \pm 0.01$ & - & - & - & - & - & $4.01 \mathrm{E}-13^{* *}$ \\
\hline & & Nylon & $12.193 \pm 0.02$ & $18.524 \pm 0.02$ & - & $22.768 \pm 0.02$ & - & - & $26.333 \pm 0.02$ & $32.555 \pm 0.02$ & & & $2.96 \mathrm{E}-37 * *$ \\
\hline & & Metalized Polyester & $12.193 \pm 0.01$ & $17.119 \pm 0.01$ & - & $20.007 \pm 0.01$ & - & - & $23.496 \pm 0.02$ & & $25.148 \pm 0.04$ & $29.915 \pm 0.01$ & $3.9 \mathrm{E}-09 * *$ \\
\hline \multirow{6}{*}{$\begin{array}{l}\text { Microbiological } \\
\text { Quality SPC } \\
\text { (CFU/g) }\end{array}$} & \multirow{3}{*}{ Control } & LDPE & $3.90 \pm 0.01$ & $4.34 \pm 0.01$ & $4.39 \pm 0.01$ & - & - & - & - & - & - & - & $1.01 \mathrm{E}-10 * *$ \\
\hline & & \begin{tabular}{|l|} 
Nylon \\
\end{tabular} & $3.90 \pm 0.01$ & $4.23 \pm 0.01$ & - & $4.34 \pm 0.01$ & - & - & - & - & - & - & $2.56 \mathrm{E}-10 * *$ \\
\hline & & \begin{tabular}{|l|} 
Metalized Polyester \\
\end{tabular} & $3.90 \pm 0.01$ & $4.14 \pm 0.01$ & - & $4.20 \pm 0.01$ & - & $4.27 \pm 0.01$ & - & - & - & - & $4.28 \mathrm{E}-10^{* * *}$ \\
\hline & \multirow{3}{*}{$\begin{array}{l}\text { Cinnamon } \\
\text { Treated }\end{array}$} & \begin{tabular}{|l|} 
LDPE \\
\end{tabular} & $3.41 \pm 0.006$ & $3.30 \pm 0.006$ & - & $3.30 \pm 0.01$ & $3.34 \pm 0.01$ & - & - & - & - & - & $1.2 \mathrm{E}-06^{* * *}$ \\
\hline & & \begin{tabular}{|l|} 
Nylon \\
\end{tabular} & $3.41 \pm 0.006$ & $3.14 \pm 0.006$ & - & $3.17 \pm 0.01$ & - & - & $3.23 \pm 0.01$ & $3.32 \pm 0.006$ & - & - & $4.67 \mathrm{E}-09 * *$ \\
\hline & & \begin{tabular}{|l|} 
Metalized Polyester \\
\end{tabular} & $3.41 \pm 0.006$ & $3.20 \pm 0.006$ & - & $3.16 \pm 0.01$ & - & - & $3.23 \pm 0.01$ & - & $3.28 \pm 0.006$ & $3.34 \pm 0.006$ & $2.46 \mathrm{E}-08^{* * *}$ \\
\hline
\end{tabular}
$\mathrm{n}=3$ (mean \pm S.D), ** $\mathrm{P}<0.01$ (Highly significant) 
Table.3 Effect of storage (at $8 \pm 1^{\circ} \mathrm{C}$ ) on sensory attributes of control and cinnamon treated sample packed under different packaging materials

\begin{tabular}{|c|c|c|c|c|c|c|c|c|c|c|c|c|c|}
\hline \multirow{2}{*}{ Characteristics } & \multirow{2}{*}{ Treatment } & \multirow{2}{*}{$\begin{array}{l}\text { Packaging } \\
\text { Materials }\end{array}$} & \multicolumn{10}{|c|}{ Storage Periods (Days) } & \multirow[t]{2}{*}{ P-value } \\
\hline & & & $\mathbf{0}$ & 4 & 5 & 8 & 9 & 10 & 12 & 14 & 16 & 18 & \\
\hline \multirow[t]{6}{*}{ Appearance } & \multirow[t]{3}{*}{ Control } & LDPE & $8.55 \pm 0.34$ & $7 \pm 0.32$ & $6 \pm 0.32$ & - & - & - & - & - & - & - & $3.19 \mathrm{E}-09 * *$ \\
\hline & & Nylon & $8.3 \pm 0.45$ & $7.8 \pm 0.40$ & - & $6.08 \pm 0.21$ & - & - & - & - & - & - & $\begin{array}{l}6.54 \mathrm{E}- \\
08^{* *}\end{array}$ \\
\hline & & $\begin{array}{l}\text { Metalized } \\
\text { Polyester }\end{array}$ & $8.42 \pm 0.38$ & $7.83 \pm 0.26$ & - & $6.92 \pm 0.38$ & - & $6 \pm 0.32$ & - & - & - & - & $\begin{array}{c}3.59 \mathrm{E}- \\
10 * *\end{array}$ \\
\hline & \multirow[t]{3}{*}{$\begin{array}{l}\text { Cinnamon } \\
\text { Treated }\end{array}$} & LDPE & $8.33 \pm 0.52$ & $8.3 \pm 0.55$ & - & $7 \pm 0.32$ & $6 \pm 0.32$ & - & - & - & - & - & $\begin{array}{c}1.31 \mathrm{E}- \\
08^{* *}\end{array}$ \\
\hline & & Nylon & $8.17 \pm 0.41$ & $7.97 \pm 0.08$ & - & $7.85 \pm 0.20$ & - & - & $7 \pm 0.32$ & $6 \pm 0.32$ & - & - & $\begin{array}{l}2.37 \mathrm{E}- \\
12 * *\end{array}$ \\
\hline & & $\begin{array}{l}\text { Metalized } \\
\text { Polyester }\end{array}$ & $8.08 \pm 0.20$ & $7.97 \pm 0.10$ & - & $7.92 \pm 0.20$ & - & - & $7.92 \pm 0.20$ & - & $6.83 \pm 0.52$ & $6 \pm 0.32$ & $\begin{array}{l}7.37 \mathrm{E}- \\
14 * *\end{array}$ \\
\hline \multirow[t]{5}{*}{ Flavour } & \multirow[t]{3}{*}{ Control } & LDPE & $7.65 \pm 0.21$ & $6.92 \pm 0.20$ & $6.02 \pm 0.16$ & - & - & - & - & - & - & - & $1.15 \mathrm{E}-09 * *$ \\
\hline & & Nylon & $7.42 \pm 0.38$ & $6.95 \pm 0.34$ & - & $6.08 \pm 0.38$ & - & - & - & - & - & - & $\begin{array}{l}4.87 \mathrm{E}- \\
05 * *\end{array}$ \\
\hline & & $\begin{array}{l}\text { Metalized } \\
\text { Polyester }\end{array}$ & $7.58 \pm 0.20$ & $7.4 \pm 0.20$ & - & $6.5 \pm 0.32$ & & $6 \pm 0.32$ & - & - & - & - & $\begin{array}{l}2.62 \mathrm{E}- \\
09^{* *}\end{array}$ \\
\hline & \multirow[t]{2}{*}{$\begin{array}{l}\text { Cinnamon } \\
\text { Treated }\end{array}$} & LDPE & $8.17 \pm 0.26$ & $8.08 \pm 0.20$ & - & $7 \pm 0.32$ & $6.08 \pm 0.20$ & - & - & - & - & - & $\begin{array}{l}5.95 \mathrm{E}- \\
12 * *\end{array}$ \\
\hline & & $\begin{array}{l}\text { Metalized } \\
\text { Polyester }\end{array}$ & $8.08 \pm 0.49$ & $8 \pm 0.32$ & - & $7.92 \pm 0.20$ & - & - & $7.42 \pm 0.20$ & & $7 \pm 0.32$ & $5.92 \pm 0.20$ & $\begin{array}{c}6.57 \mathrm{E}- \\
13 * *\end{array}$ \\
\hline \multirow[t]{6}{*}{ Body and Texture } & \multirow[t]{3}{*}{ Control } & LDPE & $8 \pm 0.32$ & $7 \pm 0.32$ & $6.92 \pm 0.21$ & - & - & - & - & - & - & - & $1.05 \mathrm{E}-05^{* *}$ \\
\hline & & Nylon & $7.92 \pm 0.20$ & $7.58 \pm 0.21$ & - & $6.92 \pm 0.20$ & - & - & - & - & - & - & $1.5 \mathrm{E}-06^{* *}$ \\
\hline & & $\begin{array}{l}\text { Metalized } \\
\text { Polyester }\end{array}$ & $8.05 \pm 0.50$ & $8.05 \pm 0.50$ & - & $7.2 \pm 0.40$ & & $7.2 \pm 0.40$ & - & - & - & - & $0.002 * *$ \\
\hline & \multirow{3}{*}{$\begin{array}{l}\text { Cinnamon } \\
\text { Treated }\end{array}$} & LDPE & $7.83 \pm 0.26$ & $7.83 \pm 0.26$ & - & $7.83 \pm 0.26$ & $7.42 \pm 0.21$ & & - & - & - & - & $0.17 *$ \\
\hline & & Nylon & $7.92 \pm 0.38$ & $7.92 \pm 0.38$ & - & $7.92 \pm 0.38$ & - & - & $7.92 \pm 0.38$ & $7.42 \pm 0.38$ & - & - & $0.11^{\mathrm{NS}}$ \\
\hline & & $\begin{array}{l}\text { Metalized } \\
\text { Polyester }\end{array}$ & $8.08 \pm 0.49$ & $8.08 \pm 0.49$ & - & $8.08 \pm 0.49$ & - & - & $8 \pm 0.50$ & - & $8 \pm 0.50$ & $7.5 \pm 0.32$ & $0.201^{\mathrm{NS}}$ \\
\hline \multirow{6}{*}{$\begin{array}{l}\text { Overall } \\
\text { Acceptability }\end{array}$} & \multirow[t]{3}{*}{ Control } & LDPE & $8 \pm 0.32$ & $6.92 \pm 0.38$ & $6.05 \pm 0.24$ & - & - & - & - & - & - & - & $8.2 \mathrm{E}-08 * *$ \\
\hline & & Nylon & $7.92 \pm 0.21$ & $7.42 \pm 0.21$ & - & $6.47 \pm 0.33$ & - & - & - & - & - & - & $\begin{array}{l}1.94 \mathrm{E}- \\
07 * *\end{array}$ \\
\hline & & $\begin{array}{l}\text { Metalized } \\
\text { Polyester }\end{array}$ & $8.05 \pm 0.51$ & $8.05 \pm 0.51$ & - & $7.37 \pm 0.38$ & - & $6.97 \pm 0.26$ & - & - & - & - & $0.0004 * *$ \\
\hline & \multirow{3}{*}{$\begin{array}{l}\text { Cinnamon } \\
\text { Treated }\end{array}$} & LDPE & $7.83 \pm 0.26$ & $7.83 \pm 0.26$ & - & $7.5 \pm 0.32$ & $7 \pm 0.32$ & - & - & - & - & - & $0.001 * *$ \\
\hline & & Nylon & $7.92 \pm 0.38$ & $7.92 \pm 0.38$ & - & $7.92 \pm 0.38$ & - & - & $7.5 \pm 0.32$ & $7.08 \pm 0.38$ & - & - & $0.0012 * *$ \\
\hline & & $\begin{array}{l}\text { Metalized } \\
\text { Polyester }\end{array}$ & $8.08 \pm 0.49$ & $8.08 \pm 0.49$ & - & $8.08 \pm 0.49$ & - & - & $7.5 \pm 0.45$ & - & $7.3 \pm 0.27$ & $7 \pm 0.32$ & $0.0001 * *$ \\
\hline
\end{tabular}

$\mathrm{n}=3$ (mean \pm S.D), $* * \mathrm{P}<0.01$ (Highly significant), $* \mathrm{P}<0.05$ (Significant), $\mathrm{ns}=$ non-significant. 
Fig.1 Effect of storage on physic-chemical and microbiological quality of control and treated paneer samples
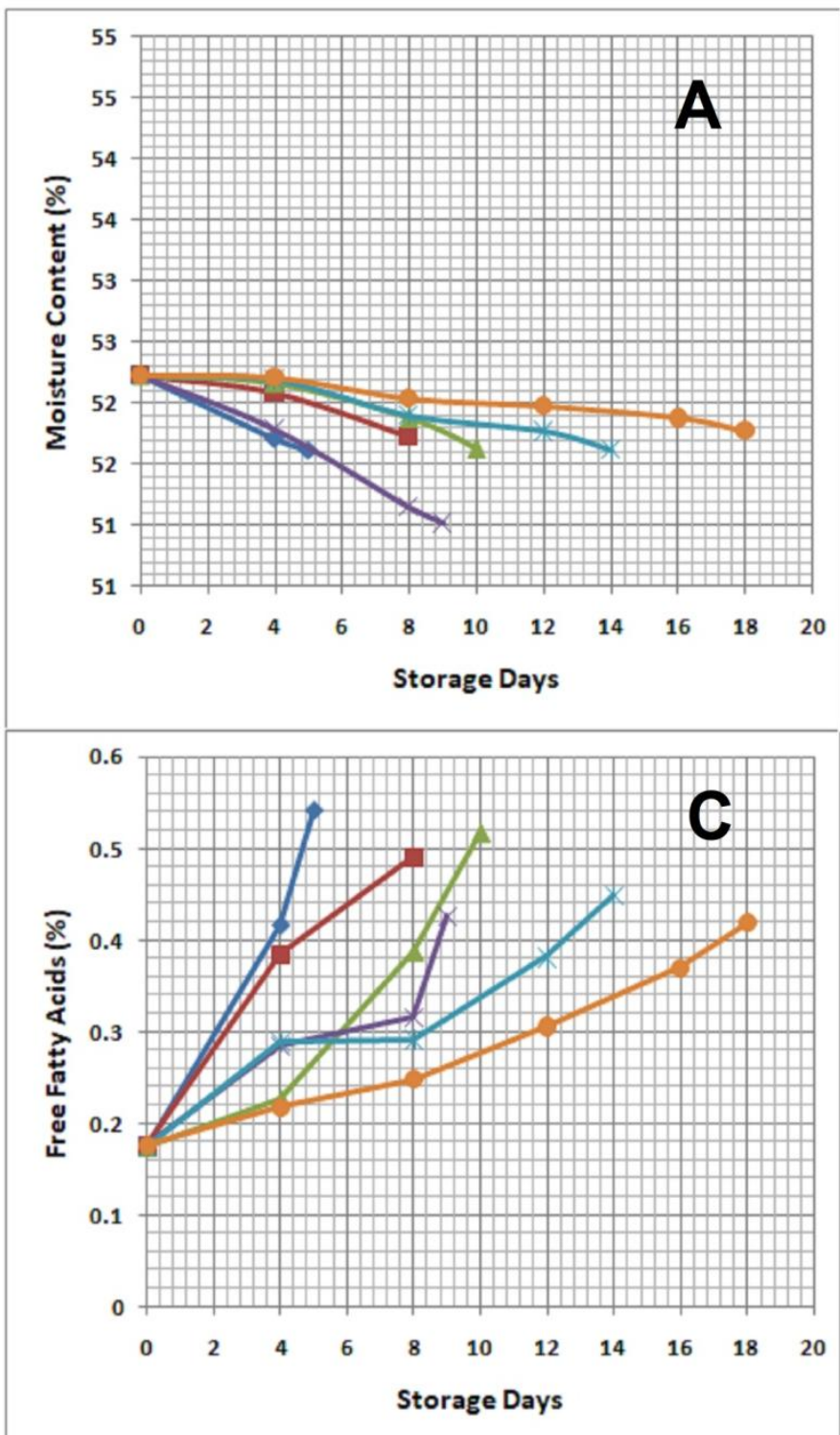
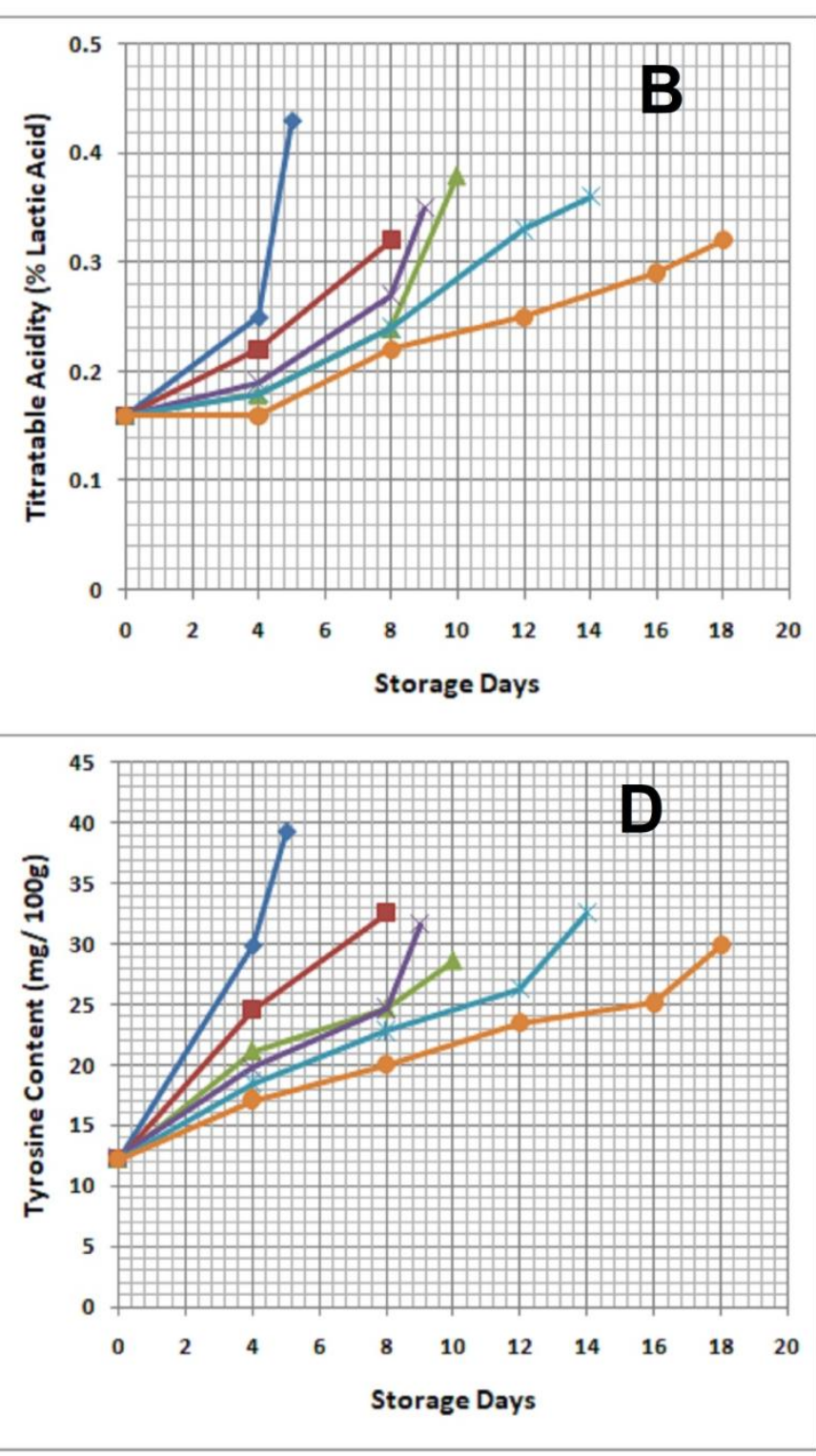

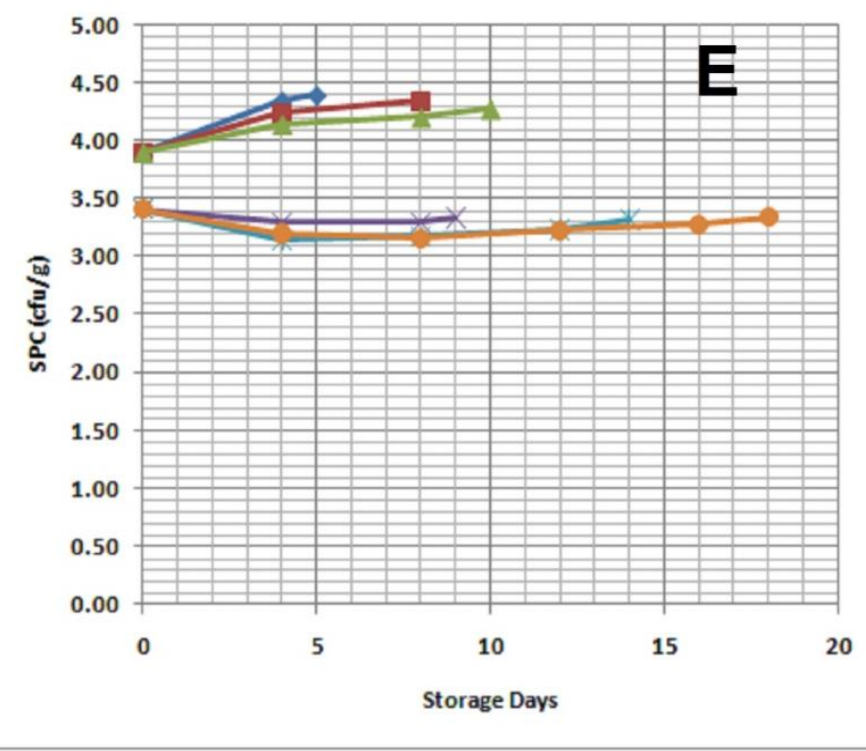

$\rightarrow$ Control Paneer in LDPE
$\rightarrow$-Control Paneer in Nylon
- Control Paneer in Metalized Polyester
- Cinnamon Treated Paneer in LDPE
- Cinnamon Treated Paneer in Nylon
-Cinnamon Treated Paneer in Metalized
Polyester 
Fig.2 Effect of storage on organoleptic quality of control and treated paneer samples

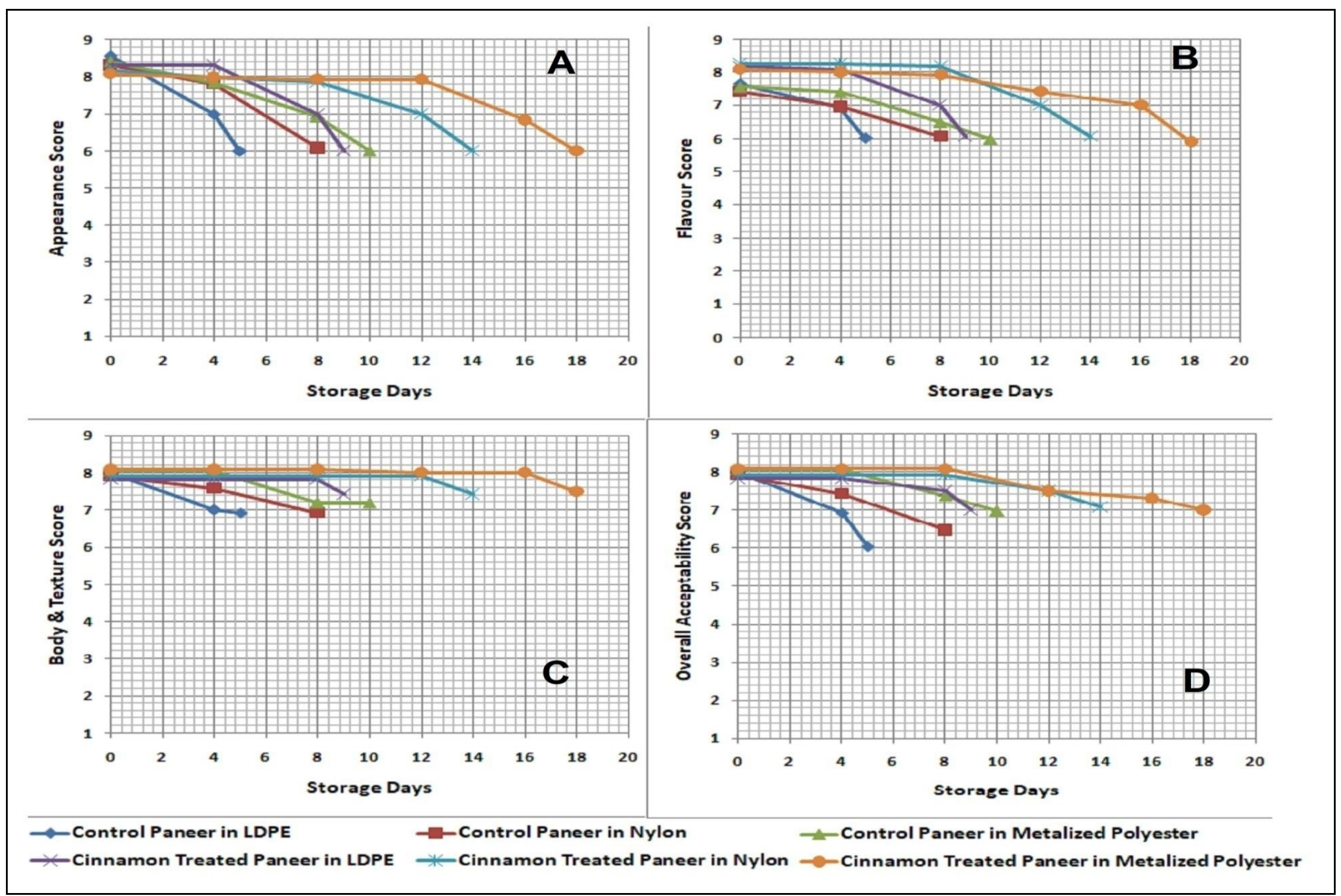




\section{Changes in microbiological quality}

There was highly significant $(\mathrm{P}<0.01)$ variation in standard plate count of all the samples with the increase in storage period.

\section{Control samples}

Individually, the standard plate count (log $\mathrm{cfu} / \mathrm{g}$ ) of control sample increases from an initial 3.90 to 4.27 in 10 days, to 4.34 in 8 days and to 4.39 in 5 days when packed with MP, NP and LDPE, respectively, (Table 1 and Figure 1). The increase in standard plate count of control sample was increased steeply with the increase in storage period mostly due to more availability favorable condition for the growth of a wide variety of organisms in stored product (Meenu Gupta, 1985 and Ghodekar, 1992). Pal et al., (1993) and Pal (1998) also observed similar trends of increase in standard plate count of fresh paneer sample when stored at $8 \pm 1^{\circ} \mathrm{C}$.

\section{Cinnamon treated samples}

The standard plate count of cinnamon treated paneer samples decreased highly significant $(\mathrm{P}<0.01)$ from an initial 3.41 to 3.34 in 18 days with MP, to 3.32 in 14 days with NP and to 3.34 in 9 days with LDPE (Table 1 and Figure 1). The decrease in standard plate count of cinnamon treated paneer samples was mostly due to antimicrobial action of cinnamaldehyde of cinnamon plant essential oil (Helander et al., 1998; Wendakoon and Sakaguchi, 1995), similar results were observed earlier by Kumar (1989), Singh et al., (1989) and Sachdeva and Singh (1990b) with using different antimicrobial agents during storage of paneer. The decrease in standard plate count of paneer samples during storage treated with different antimicrobial agents were also reported earlier by various research workers (Kumar, 1989, Singh et al., 1989 and Sachdeva and Singh, 1990b).

While the coliform count and yeast and mould count $(\log \mathrm{cfu} / \mathrm{g})$ of all the control samples packaged in different packaging material was within BIS standard throughout the storage period and varying from an initial 1.17 to 1.84 and from an initial 1.79 to 2.25 , respectively, at the end of storage and that of all the paneer samples treated with different plant essential oils packaged in different packaging material was almost nil throughout the storage period.

\section{Changes in appearance score}

There was slight decrease in appearance of all the samples with the increase in storage period. The appearance of all the samples was towards yellowish tint at the end of storage period, but within desirable range.

\section{Control sample}

Individually, the appearance of control sample decreases highly significantly $(\mathrm{P}<0.01)$ from an initial 8.5 to 6.0 in 10 days, to 6.0 in 8 days and to 6.0 in 5 days when packed with MP, NP and LDPE, respectively, (Table 2 and Figure 2). Similar results were also observed earlier by various research workers (Agarwal, 2001; Bambha, 1998; Sachdeva, 1983 and Sweta, 2004) during storage of paneer samples.

\section{Cinnamon treated sample}

The appearance of cinnamon treated paneer samples decreased highly significantly $(\mathrm{P}<0.01)$ from an initial 8.0 to 6.0 in 18 days with MP, to 6.0 in 14 days with NP and to 6.0 in 9 days with LDPE. The decrease in appearance score of cinnamon treated paneer sample was comparatively with slower extent as compared to control sample that could be mostly due to antimicrobial action of cinnamaldehyde of cinnamon plant essential oil that inhibit other biochemical reaction resultant in deterioration of product.

\section{Changes in flavour score}

There was gradual decrease in flavour score of paneer samples during storage. 


\section{Control sample}

Individually, the flavour score of control sample decreased highly significantly $(\mathrm{P}<0.01)$ from an initial 7.5 to 6.0 in 10 days, in 8 days and in 5 days when packed with MP, NP and LDPE, respectively, (Table 2 and Figure 2).

\section{Cinnamon treated sample}

The flavour score of paneer samples treated with cinnamon decreased highly significantly $(\mathrm{P}<0.01)$ from an initial 8 to 6 in 18 days with MP, to 6 in 14 days with NP and to 6 in 9 days with LDPE (Table 2 and Figure 2).

\section{Changes in body and texture}

The body and texture of all the samples was within desirable range except control samples packaged in different packaging material.

\section{Control sample}

There was highly significantly $\quad(\mathrm{P}<0.01)$ decreased in body and texture score of control samples from an initial 8. 0 to 7.0 in 10 days, in 8 days and in 5 days when packed with MP, NP and LDPE, respectively, with the increase in storage period (Table 2 and Figure 2).

\section{Cinnamon treated sample}

Individually, the body and texture score of paneer samples treated with cinnamon decreased from an initial 8.0 to 7.5 in 18 days with MP, in 14 days and with NP and decreased significantly $(\mathrm{P}<0.05)$ in 9 days with LDPE (Table 2 and Figure 2).

\section{Changes in overall acceptability}

There was highly significantly $\quad(\mathrm{P}<0.01)$ decrease in overall acceptability of all the samples with the increase in storage period. The overall acceptability of all the samples was within desirable range, except slightly poorer for control samples as compared to others and exhibited natural look when packed in different packaging material.

\section{Control sample}

Individually, the overall acceptability score of control sample decreased highly significantly $(\mathrm{P}<0.01)$ from an initial 8. 0 to 7.0 in 10 days, to 6.5 in 8 days and to 6.0 in 5 days when packed with MP, NP and LDPE, respectively, (Table 2 and Figure 2).

\section{Cinnamon treated sample}

The overall acceptability of paneer samples treated with cinnamon decreased highly significantly $(\mathrm{P}<0.01)$ from an initial 8.0 to 7.0 in 18 days with MP, in 14 days with NP, and in 9 days with LDPE (Tables 2, 3 and Figure 2).

There was no major perceivable defect observed in stored samples, except control, but the decrease in flavour score to less than 6.0 during storage limited their shelf life. On decreased flavour basis, control paneer samples showed shelf life of only 10 days with metalized polyester, 8 days with nylon and 5 days with LDPE, while cinnamon treated samples showed shelf life of 18 days with metalized polyester, 14 days with nylon and 9 days with LDPE at $8 \pm 1^{\circ} \mathrm{C}$. Thus, it can be concluded that cinnamon oil can be a good natural additive as an antimicrobial agent in real food environment and combination of cinnamon and metalized polyester as a packaging material could be helpful to overcome the problem of limited shelf life of paneer.

\section{Acknowledgement}

Authors are highly thankful to Department of Food Technology and GJUS\&T, Hisar, Haryana for providing research oriented environment and great opportunity for successful completion of this work.

\section{References}

Alzoreky, N.S. and Nakahara, K., 2002. Antimicrobial activity ofextracts from some edible plants commonly consumed in Asia. Int. J. Food Microbiol. 80, 223- 
230.

Anonymous, 2017. http://www.nddb.org/ information/stats/milkprodindia. Assessed on 11-07-2017.

AOAC, 1975. Official methods of analysis of the Association of Official Analytical Chemists. $13^{\text {th }}$ Ed. W. Horwitz ed. Washington, D.C.

APHA, 1978. Standard Methods for the examination of Dairy Products. $14^{\text {th }}$ Ed. E.H. Marth, ed. Washington, D.C.

Bambha, P.P., 1988. Bacteriological and Biochemical Changes in Paneer and Khoa during Storage at Refrigeration Temperature, M.Sc. Thesis Submitted to Kurukshetra University, Kurukshetra.

Beuchat, L.R., and Golden, D.A., 1989. Antimicrobials occurring naturally in foods. Food Technol., 43 (1), 134-142.

Bhattacharya, D.C., Mathur, O.N.; Srinivasan, M.R. and Samlik, O. 1971. Studies on the Methods of Production and Shelf life of Paneer (Cooking Type of Acid Coagulated cottage cheese). J. Food Sci. Technol., 8 (5): 117- 120.

BIS, 2001a. Chemical examination of milk. In: Hand book of food analysis: (Part XI) Dairy products. Bureau of Indian Standards $\left(3^{\text {rd }}\right.$ reprint), Manak Bhavan, New Delhi, and pp: 21-45.

Davidson, P.M., and Naidu, A.S. 2000. PhytoPhenols. In: Naidu, A.S. (Ed.), Natural Food Antimicrobial Systems. CRC Press, Boca Raton, FL, pp. 265-294.

Deans, S.G., and Ritchie, G. 1987. Antimicrobial properties of plant essential oils. Int. J. Food Microbiol. 5, 165-180.

Deans, S.G., Noble, R.C., Hiltunen, R., Wuryani, W. and Penzes, L.G. 1995. Antimicrobial and antioxidant properties of Syzygium aromaticum (L.) Merr. \& Perry: impact upon bacteria, fungi and fatty acid levels in ageing mice. Flav. Frag. J. 10, 323-328.

Dorman, H.J.D., and Deans, S.G. 2000. Antimicrobial agents from plants: antibacterial activity ofplant volatile oils. J. Appl. Microbiol. 88, 308-316.

Ghodekar, D.R., 1989. Factors Effecting
Quality of Paneer. Indian Dairyman, 41(3):161-164.

Goyal, G.K., 1988. Need for Mechanized Handling and Proper Packaging of Milk Based Sweets, Beverages and Fermented Dairy Products. Beverage \& Food World, 15(1): 57-58.

Gupta, M., 1985 Studies on Food Poisoning Organisms in Paneer, M.Sc. Thesis submitted to Kurukshetra University, Kurukshetra.

Helander, I.M., Alakomi, H.-L., Latva-Kala, K., Mattila-Sandholm, T., Pol, I., Smid, E.J., Gorris, L.G.M. and Von Wright, A. 1998. Characterization of the action of selected essential oil components on Gramnegative bacteria. J. Agric. Food Chem., 46, 3590-3595.

Hull, M.E., 1947. Studies on milk proteins. II. Colorimetric determination of the partial hydrolysis of the proteins in milk. $J$. Dairy Sci., 30, 881-884.

IS, 1977 -Part II: 1224: Determination of fat content in cheese and similar products. Manak Bhavan, New Delhi-110002.

IS, 1983. 10484: Determination of moisture content in paneer and similar products. Manak Bhavan, New Delhi-110002.

Kim, H.Y., Lee, Y.J., Hong, K.-H., Kwon, Y.K., Sim, K.-C., Lee, J.-Y., Cho, H.-Y., Kim, I.-S., Han, S.-B., Lee, C.-W., Shin, I.-S. And Cho, J.S. 2001. Isolation ofantimicrobial substances from natural products and their preservative effects. Food Sci. Biotechnol. 10 (1), 59-71.

Kim, J., Marshall, M.R. and Wei, C. 1995a. Antimicrobial activity of some essential oil components against five food borne pathogens. J. Agric. Food Chem. 43, 2839-2845.

Kumar, P., 1989. Enhancement of Shelf Life of Paneer with Food Additives, M.Sc. Dissertation, Kurukshetra Univ., Kurukshetra.

Kumara, A., and Kalimoddin, M. 2002. Bacteriological quality of khoa and paneer samples from local and standard shops. J. Dairy Res, 14(1): 135-139.

Lawrence, A.J., The determination of lactose in 
milk products. Aust J Dairy Technol. 1968; 23:103.

Lis-Balchin, M., Deans, S.G. and Eaglesham, E. 1998b. Relationship between bioactivity and chemical composition of commercial essential oils. Flav. Frag. J. 13, 98-104.

Manefee, S.C., and Overman, O.D. (1940) A semimicro-Kjeldahl method for the determination of total nitrogen in milk. $J$. Dairy Sci., 23:1177-1185.

Mistry, C.D., Singh, S. and Sharma, R.S. 1990. Some Physico-chemical Changes during Storage of Paneer Prepared from Cow Milk by Altering Salt- Balance of Milk, XXIII Int. Dairy Congr., Montreal, 8- 12 Oct., 1990, Vol. II: 518.

Packiyasothy, E.V., and Kyle, S. 2002. Antimicrobial properties of some herb essential oils. Food Australia 54 (9), 384 387.

Pal, D., and Garg, F.C. 1989. Studies on the Utilization of Sweet-cream Butter Milk in Manufacturing of Paneer. J. Fd Sci. Technol, 26: 259- 264.

Pal, M. A., Yadav, P. L. and Sanyal, M. K. 1993. Effect of Paraffining on the Physico-Chemical, Microbiological and Sensory Characteristics of Low fat Paneer at Low Temperature Storage. Indian J. Dairy Sci., 46: 519-524

Pal, M.A., 1998. Microbiologically Related Biochemical Transformations in Paneer during Storage. Indian J. Microbiol, 38 (1), 21- 22.

Rai, S., 2004. Studies on the Extension of Shelf Life of Paneer through Modified Atmosphere Packaging (MAP). M.Sc. Thesis submitted to University of Allahabad. Allahabad.

Rai, S., Goyal, G.K. and Rai, G. K. (2008) Effect of Modified Atmosphere Packaging and Storage on the Chemical
Quality of Paneer. J. Dairying, Food Home Sci. 27(1).

Rao, M.N., Rao, B.V.R. and Rao, T.J. 1984. Paneer from Buffalo Milk. Ind. J. Dairy Sci., 37:50-53.

Sachdeva, S., 1983. Production, Packaging and Preservation of Paneer, Ph.D. Thesis submitted to Kurukshetra Univ., Kurukshetra.

Sachdeva, S., and Singh, S. 1990b. Shelf Life of Paneer as Affected by Antimicrobial Agents- Part II Effect on Microbiological Characteristics. Indian J. Dairy Sci., 43: 64-67.

Shukla, F.C., Madhu, B. and Sekhon, K.S. 1984. Studies on the Technological Aspects of Processing and Preservation of Paneer, I.C.A.R Rep., New Delhi.

Sindhu, J.S., Arora, S. and Nayak, S. K. 2000. Physico-chemical Aspects of Indigenous Dairy Products. Indian Dairyman, 52(10): 51- 64

Singh, L., Mohan, M.S.; Puttalingamma, V. and Sankaran, R. 1989. Preservation of Paneer by Sorbic Acid, J. Food Sci. Technol, 26: 129- 132.

Srivastava, D., 2004. Studies on the Influence of Modified Atmosphere Packaging (MAP) on the Microbial Population and Shelf Life of Paneer. M.Sc. Thesis submitted to University of Allahabad. Allahabad.

Thomas, W. R., Harper, W. J. and Gould, I. A. 1954. Free fatty acid content of fresh milk as related to portions of milk drawn. $J$. Dairy Sci., 37, 717-723.

Wendakoon, C.N., and Sakaguchi, M. 1995. Inhibition of amino acid decarboxylase activity of Enterobacter aerogenes by active components in spices. J. Food Protect. 58 (3), 280- 283.

\section{How to cite this article:}

Anju Boora Khatkar, Aradhita Ray and Amarjeet Kaur. 2017. Studies on Shelf Life Extension of Paneer with the Addition of Plant Essential Oil and Different Packaging Materials. Int.J.Curr.Microbiol.App.Sci. 6(9): 376-389. doi: https://doi.org/10.20546/ijcmas.2017.609.047 